\title{
Low water quality in tropical fishponds in southeastern Brazil
}

\author{
SIMONE M. COSTA ${ }^{1,3}$, ELEONORA APPEL $^{1}$, CARLA F. MACEDO ${ }^{2}$ and VERA L.M. HUSZAR ${ }^{1}$ \\ ${ }^{1}$ Universidade Federal do Rio de Janeiro, Museu Nacional, \\ Quinta da Boa Vista, 20940-040 Rio de Janeiro, RJ, Brasil \\ ${ }^{2}$ Universidade Federal do Recôncavo da Bahia, Centro de Ciências Agrárias, Ambientais e Biológicas, \\ Rua Rui Barbosa, 710, Centro, 44380-000 Cruz das Almas, BA, Brasil \\ ${ }^{3}$ Universidade Federal do Rio de Janeiro, Instituto de Biofísica Carlos Chagas Filho, \\ Laboratório de Ecotoxicologia e Toxicologia de Cianobactérias, \\ Av. Carlos Chagas Filho, 372, Cidade Universitária, Ilha do Fundão, 21941-902 Rio de Janeiro, RJ, Brasil
}

Manuscript received on March 7, 2013; accepted for publication on September 9, 2013

\begin{abstract}
Expansion of aquaculture around the world has heavily impacted the environment. Because fertilizers are needed to raise fish, one of the main impacts is eutrophication, which lowers water quality and increases the frequency of algal blooms, mostly cyanobacteria. To evaluate whether the water quality in 30 fishponds in southeastern Brazilian met the requirements of Brazilian legislation, we analyzed biotic and abiotic water conditions. We expected that the high nutrient levels due to fertilization would cause low water quality. We also analyzed cyanotoxins in seston and fish muscle in some systems where cyanobacteria were dominant. The fishponds ranged from eutrophic and hypereutrophic with high phytoplankton biomass. Although cyanobacteria were dominant in most of the systems, cyanotoxins occurred in low concentrations, possibly because only two of the 12 dominant species were potential producers of microcystins. The high phosphorus concentrations caused the low water quality by increasing cyanobacteria, chlorophyll- $a$, turbidity, and thermotolerant coliforms, and by depleting dissolved oxygen. We found that all the 30 systems were inappropriate for fish culture, according to Brazilian legislation, based on at least one of the parameters measured. Furthermore, there was not any single system in the water-quality thresholds, according to the Brazilian legislation, to grow fish. Our findings indicate the need for better management to minimize the impacts of eutrophication in fishponds, in addition to a rigorous control to guarantee good food.
\end{abstract}

Key words: cyanobacteria, cyanotoxins, eutrophication, fish culture.

\section{INTRODUCTION}

World aquaculture production has increased 39-fold from 1957 to 2008 and contributes significantly to global fish production for human consumption, now surpassing the supply of wild-caught fish (SamuelFitwir et al. 2012). At the same time, impacts on environmental conditions have also increased (Cao

Correspondence to: Vera Lucia de Moraes Huszar

E-mail:vhuszar@gbl.com.br et al. 2007). Classical impacts include pathogens, introduction of genetically modified organisms, additives and drugs, antimicrobial resistance, spread of diseases, escapes, overexploitation of wild species, and nutrient enrichment (Pelletier et al. 2007). Recently, aquaculture ponds have also been identified as being a $\mathrm{CO}_{2}$ sinks (Boyd et al. 2010) as well as an $\mathrm{N}_{2} \mathrm{O}$ source to the atmosphere (Hu et al. 2012). 
Inorganic (nitrogen and phosphorus) fertilizers applied to fishponds are needed to grow fish by stimulating plankton growth and increasing production of high-protein fish biomass (Boyd and Queiroz 1997, Neori 2011). Organic fertilizers or manures from animal wastes or agricultural byproducts are also used, which are either directly consumed by the fish (or by invertebrate fishfood organisms) or decompose slowly to release inorganic nutrients (Boyd and Queiroz 1997). However, only a portion of the nutrients from fertilizers is incorporated into the final product (Hargreaves and Tucker 2003). The remaining part is mineralized in the sediment, and then released into the water column or carried by the effluents to the watershed (Boyd and Queiroz 2001, Yokoyama 2003, Zhang et al. 2006). The movement of fish (bioturbation) also resuspends sediment, enhancing mineralization (Phan-Van et al. 2008).

The consequence of nutrient enrichment is an increase in eutrophication, one of the main impacts from aquaculture. This leads to, for example, the reduction of oxygen, outgassing of hydrogen sulfide, and phytoplankton blooms (Boyd 2006). Cyanobacteria is the main algal group forming blooms in enriched waters (Paerl and Huissman 2009), including species that are potentially toxic to humans and animals (Carmichael 1997, Paerl et al. 2011). Cyanobacteria is able to dominate in high biomass in conditions of high total phosphorus concentrations (Trimbee and Prepas 1987, Moss et al. 2011), low TN:TP ratios (Smith 1983), high temperature (Paerl and Huisman 2008, Kosten et al. 2012), low light (Smith 1986, Scheffer et al. 1997), and high $\mathrm{pH} /$ low $\mathrm{CO}_{2}$ (Caraco and Miller 1998).

In spite of the importance of phytoplankton for the growth of fish in freshwater, few studies in Brazil have examined blooms and dominant algal groups in these systems. In these few studies, cyanobacteria have been reported as the most abundant algae (Sant'Anna et al. 2006, Minillo and Montagnolli 2006). They are potentially producers of toxins (e.g., hepatotoxins, neurotoxins) and compounds with an unpleasant taste and odor (e.g., geosmin) (Dzialowski et al. 2009, Paerl et al. 2011). Toxins can accumulate in fish muscle or viscera (Magalhães et al. 2001, Soares et al. 2004, Ibelings and Chorus 2007, Romo et al. 2012). In the state of São Paulo, Eler and Espíndola (2006) found microcystins in $46 \%$ of the 30 fishponds analyzed by them, of which two were at very high levels. However, as far as we know, there is no information about bioaccumulation in the muscle tissue of fish from commercial fishponds in Brazil.

To evaluate the water quality in 30 fishponds in southeastern Brazil, we analyzed biotic and abiotic water conditions and compared them to levels mandated by Brazilian legislation. We expected that the high nutrient levels resulting from fertilization would indicate low water quality. We also analyzed cyanotoxins in fish muscle and the seston fraction in some systems where cyanobacteria occurred in high abundance. We found low water quality in most of the fishponds.

\section{MATERIALS AND METHODS}

STUDY SITES

The 30 systems studied are located in southeastern Brazil, in the densely populated (366 inhabitants $\mathrm{km}^{-2}$ ) state of Rio de Janeiro (Figure 1). The regional climate is tropical (Aw, Köppen classification) with a historical total annual precipitation of $1172 \mathrm{~mm}$, and annual mean minimum temperature of $20.9^{\circ} \mathrm{C}$ and maximum of $27.2^{\circ} \mathrm{C}$; with dry winters and wet summers (SIMERJ 2011). In most of the 30 fishponds, rotifers were dominant in richness and abundance, while cyclopoid copepods were in biomass (Loureiro et al. 2011).

\section{SAMPLE AND DATA COLLECTIONS}

The following variables were obtained from direct, structured and semi-structured interviews with the owners and employees during field work: type of 


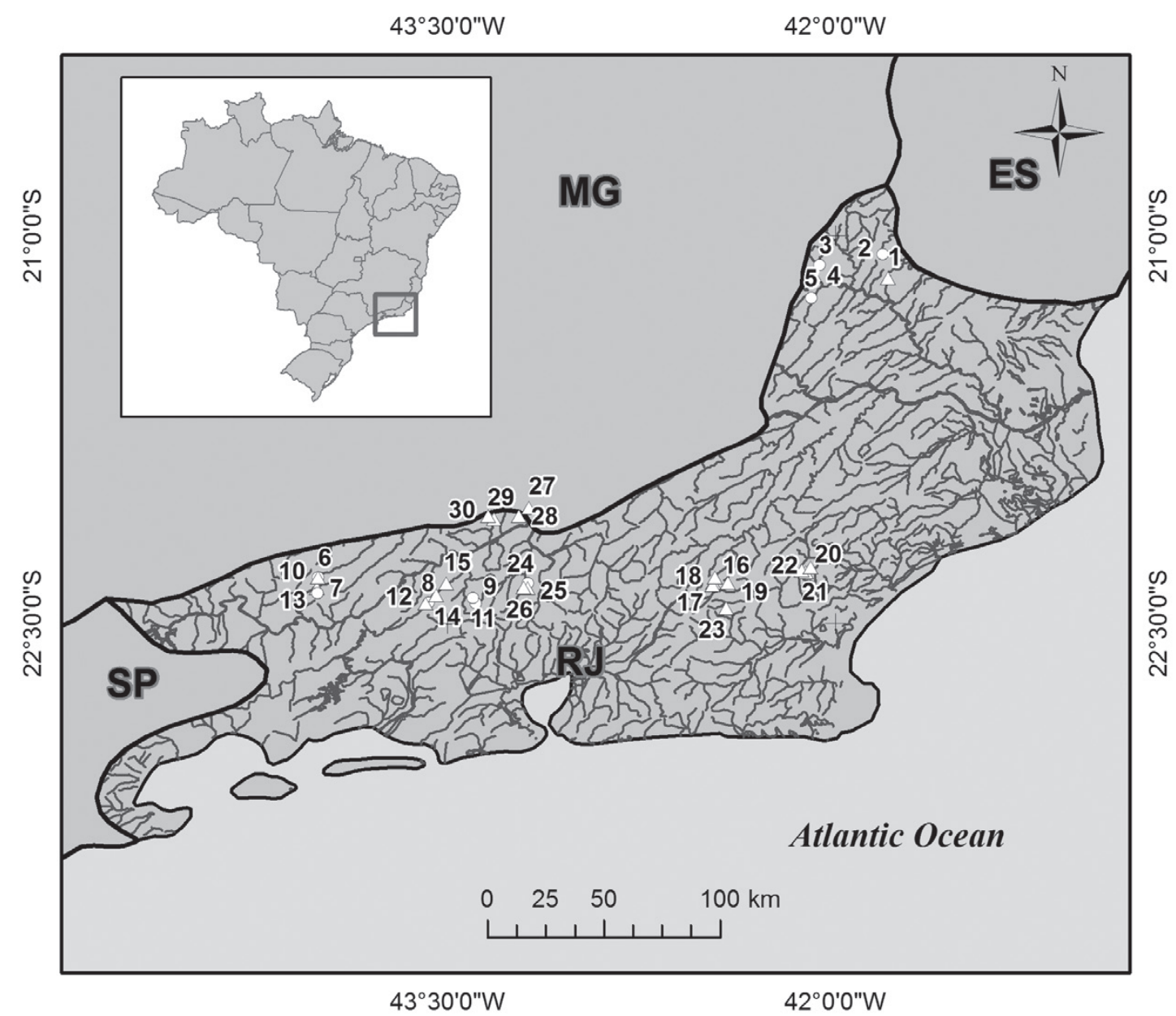

Figure 1 - Map of the state of Rio de Janeiro, showing the sampled fishponds. Circles = fee-fishing systems; triangles = fish-farming systems. MG = Minas Gerais, ES = Espírito Santo, RJ = Rio de Janeiro, SP = São Paulo.

activity (fee-fishing, fish-farming), water source (spring, stream), bottom (earthen, concrete), rearing system (multiple, monoculture), fertilizers (organic, inorganic), and fish stocking rates.

Water samples for nutrients, chlorophyll- $a$, and phytoplankton were taken once, using a van Dorn bottle at the subsurface $(0.3 \mathrm{~m})$ between November 2005 and January 2006, in the middle of each of the 30 fishponds. Thermotolerant coliforms were sampled directly from the surface water were sterile flasks. Water temperature and dissolved oxygen (YSI model 52), pH (Digimed), conductivity (Digimed), turbidity (Alfakit model AT), and water transparency
(Secchi depth extinction) were measured in situ. Discharge inflow was measured by the volumetric method, which is based on the time taken for a given water flow to occupy a container of known volume. System area and volume were calculated from local measurements. Residence time was estimated as discharge inflow divided by the fishpond volume. Water samples for nutrients were divided for analysis of total (phosphorus, TP; nitrogen, TN) and dissolved nutrients (soluble reactive phosphorus, SRP; ammonium, $\mathrm{N} \mathrm{NH}_{4}{ }^{+}$; nitrate, $\mathrm{N}^{-\mathrm{NO}_{3}}{ }_{3}^{-}$; nitrite, $\mathrm{N} . \mathrm{NO}_{2}{ }^{-}$). A fraction of the water sample for total nutrients was directly frozen at $-18^{\circ} \mathrm{C}$, and for 
dissolved nutrients the water was filtered through Whatman $\mathrm{GF} / \mathrm{C}$ filters and then frozen at $-18^{\circ} \mathrm{C}$ until further processing. Phytoplankton samples were preserved with Lugol's Iodine solution.

Five of the 30 systems where cyanobacteria concentrations were above 20,000 cells $\mathrm{mL}^{-1}$ (ponds $12,18,20,24$, and 25) were selected for microcystin analysis (seston and fish muscle). Samples were taken in 2005 and repeated in 2008. To obtain the seston, $2 \mathrm{~L}$ of water were filtered on Whatman GF/C filters and then frozen at $-18^{\circ} \mathrm{C}$ until microcystin analysis. Fish (Nile tilapia, Oreochromis niloticus) were collected in each system for further analysis of microcystins in muscle. Inflow volume was measured in systems where there was inflow.

\section{SAMPLE ANALYSIS}

Kjeldahl nitrogen, $\mathrm{N}_{\mathrm{NO}}{ }_{2}^{-}, \mathrm{N}_{\mathrm{NO}}{ }_{3}^{-}, \mathrm{N}_{\mathrm{NH}}{ }_{4}^{+}$, $\mathrm{TP}$ and SRP were analyzed according to Mackereth et al. (1978) and Wetzel and Likens (1990). Phytoplankton population densities (cells $\mathrm{mL}^{-1}$ ) were estimated using the settling technique (Utermöhl 1958) in an inverted microscope (Zeiss Oberkochen, Axiovert 10) under 400x magnification. Chlorophyll- $a$ concentrations were estimated by the colorimetric method after extraction in 90\% acetone (APHA 2005). Thermotolerant coliforms (MPN $100 \mathrm{~mL}^{-1}$ ) were analyzed according to Standard Methods (APHA 2005).

For microcystin analysis in the seston, the filter was extracted three times with MeOH:TFA $0.1 \%$ for $1 \mathrm{~h}$, and the supernatant was combined and evaporated (dry extracts). The fish muscle for microcystin analysis was weighed and subsequently extracted three times with $100 \% \mathrm{MeOH}$ for $1 \mathrm{~h}$; the extract was centrifuged at $3000 \mathrm{rpm}$ for $15 \mathrm{~min}$ and the supernatant was evaporated, resuspended in $20 \mathrm{~mL}$ of Milli-Q water and passed through an activated HP-20 column, eluted with 10\%, 20\% and $30 \%$ methanol and $\mathrm{MeOH}$ : TFA $0.1 \%$. The fraction $\mathrm{MeOH}:$ TFA $0.1 \%$ was collected and the extract was evaporated (dry extracts). The dry extracts from seston and muscle samples were resuspended in $2 \mathrm{~mL}$ of Milli-Q water, and then filtered on a cellulose acetate filter with $0.45 \mu \mathrm{m}$ mesh. These solutions were analyzed by ELISA (EnzymeLinked Immunosorbent Assay) using a microplate kit for MCYSTs (Beacon Analytical Systems Inc.) following the manufacturer's protocol, with two replicates per sample.

DATA ANALYSIS

Theoretical residence time was estimated from the fishpond volume divided by inflow volume. TN was calculated from the sum of Kjeldahl nitrogen and $\mathrm{N}^{-\mathrm{NO}_{3}}{ }^{-}$. Dissolved inorganic nitrogen (DIN) was considered as the sum of $\mathrm{N}^{-\mathrm{NO}_{2}}{ }^{-}$, N.NO${ }_{3}{ }^{-}$and N.NH${ }_{4}{ }^{+}$. TN:TP ratios were estimated on a molar basis.

Although fishponds are expected to be nutrient-enriched, the proportion of nutrients can become limiting to phytoplankton growth. To evaluate the differences in potential N-limitation to phytoplankton growth in the systems, we used the following indicators (Kosten et al. 2009): (i) TN:TP ratios in the pond water; ponds below 20 (molar based) were considered N-limited and above 38, P-limited (Sakamoto 1966); and (ii) DIN and SRP were compared to concentrations that have generally been considered to limit phytoplankton growth. P was considered limiting below $\sim 10 \mu \mathrm{g} P / \mathrm{L}$ (Sas 1989) and N below $100 \mu \mathrm{g} \mathrm{N} / \mathrm{L}$ (Reynolds 1997). Clearly this is only an approximation, as it depends on the affinities and storage capacities of the individual species (Reynolds 1999).

The trophic state of the fishponds was assessed by TP and chlorophyll- $a$ concentrations according to Nürnberg (1996). To evaluate if the fertilizers used in the fishponds lowered water quality, we used as a criterion the Brazilian legislation, based on some selected variables (dissolved oxygen, turbidity, TP concentrations, chlorophyll- $a$, cyanobacteria abundance and thermotolerant coliforms). Class II water bodies may be used for aquaculture and fishing activities (CONAMA 357/2005). 
The statistical differences in the variables among categorical groups were tested using a nonparametric Kruskal-Wallis test. To explore the relationships between phytoplankton abundance vs. environmental variables, stepwise multiple linear regression with forward selection and Spearman correlations $\left(\mathrm{r}_{\mathrm{s}}\right)$ were used. All independent variables (except for $\mathrm{pH}$ ) and phytoplankton abundance were $\log \mathrm{x}$ transformed to attain normality. All statistical analyses were performed in Statview 5.0.

\section{RESULTS}

\section{MAIN FEATURES OF THE FISHPONDS}

Of the 30 systems, 21 were fish farms dedicated only to fattening fish (15) or to both, breeding and fattening fish (6); nine were fee-fishing ponds. The areas of the aquaculture systems ranged from 350 to $6,000 \mathrm{~m}^{2}$ and the maximum depths ranged from 0.8 to $2.0 \mathrm{~m}$ (Table I). Most fishponds used springs as the water source; 12 systems were closed with no inflow, and the others were open and high-flushing (Table II) with a median residence time of 1.9 days (0.1 to 19.2 days). Only two systems (fee-fishing) were made of concrete and the others were unlined earthen ponds. The most frequent fish species were the exotic tilapia (Tilapia rendalii) and Nile tilapia (Oreochromis niloticus), growing in monoculture or with other fish species (Table II). The stocking rates ranged from 1 to 4 fish $\mathrm{m}^{-2}$ in both the feefishing and fish-farming systems (Table II). Of the 30 ponds, $84 \%$ used organic, inorganic, or both types of fertilizers (Table II). Five fishponds, mostly fee-fishing systems, were not enriched by any type of fertilizer.

TABLE I

Range, median and mean values, and standard deviation (SD) of the limnological variables in $\mathbf{3 0}$ fishponds.

\begin{tabular}{|c|c|c|c|c|}
\hline & Range & Median & Mean & SD \\
\hline Area $\left(\mathrm{m}^{2}\right)$ & $350-6000$ & 2450 & 2962 & 2450 \\
\hline Maximum depth (m) & $0.8-2.0$ & 1.5 & 1.4 & 0.3 \\
\hline Water temperature $\left({ }^{\circ} \mathrm{C}\right)$ & $23.2-32.7$ & 26.5 & 27.1 & 2.7 \\
\hline Dissolved oxygen $\left(\mathrm{mg} \mathrm{L}^{-1}\right)$ & $1.2-12.8$ & 4.8 & 5.7 & 2.6 \\
\hline Conductivity $\left(\mu \mathrm{S} \mathrm{cm}^{-1}\right)$ & $24.0-610.0$ & 56 & 86.8 & 104.6 \\
\hline $\mathrm{pH}$ & $5.1-9.3$ & 7.0 & 7.2 & 0.97 \\
\hline Secchi depth (m) & $0.08-0.52$ & 0.19 & 0.21 & 0.11 \\
\hline Turbidity (NTU) & $9.9-262.9$ & 51.0 & 65.2 & 52.1 \\
\hline $\mathrm{N}-\mathrm{NH}_{4}^{+}\left(\mu \mathrm{g} \mathrm{L}^{-1}\right)$ & $3.9-680.1$ & 28.1 & 75.8 & 131.9 \\
\hline $\mathrm{N}-\mathrm{NO}_{3}^{-}\left(\mu \mathrm{g} \mathrm{L}^{-1}\right)$ & $2.0-1502.3$ & 23.2 & 155.5 & 318.5 \\
\hline $\mathrm{N}-\mathrm{NO}_{2}^{-}\left(\mu \mathrm{g} \mathrm{L}^{-1}\right)$ & $0.5-19.4$ & 3.0 & 5.1 & 4.9 \\
\hline Dissolved inorganic nitrogen $\left(\mu \mathrm{g} \mathrm{L}^{-1}\right)$ & $14.4-1528.8$ & 79.1 & 236.5 & 389 \\
\hline Soluble reactive phosphorus $\left(\mu \mathrm{g} \mathrm{L}^{-1}\right)$ & $4.6-45.5$ & 12.2 & 16.5 & 10.9 \\
\hline Total nitrogen $\left(\mu \mathrm{g} \mathrm{L}^{-1}\right)$ & $112.0-4732.0$ & 560 & 836.2 & 900.8 \\
\hline Total phosphorus $\left(\mu \mathrm{g} \mathrm{L}^{-1}\right)$ & $33.4-669.5$ & 173.2 & 213.3 & 171.4 \\
\hline Total nitrogen/total phosphorus (by atom) & $0.7-171.3$ & 9.4 & 18.9 & 32.34 \\
\hline Chlorophyll- $a\left(\mu \mathrm{g} \mathrm{L}^{-1}\right)$ & $8.7-344.0$ & 82.0 & 104.4 & 84.8 \\
\hline Cyanobacterial abundance $\left(10^{3}\right.$ cells $\left.\mathrm{mL}^{-1}\right)$ & $2.9-4758.0$ & 480.7 & 637.0 & 1180.9 \\
\hline Thermotolerant coliforms (NMP $100 \mathrm{~mL}^{-1}$ ) & $2-160000$ & 1350.0 & 25705 & 50791 \\
\hline
\end{tabular}




\section{WATER CONDITIONS}

There was limited variation in temperatures, but dissolved oxygen concentrations and conductivity varied over wide ranges (Table I). Dissolved oxygen levels were below $5 \mathrm{mg} \mathrm{L}^{-1}$ in $47 \%$ of the fishponds. The $\mathrm{pH}$ was neutral on average (median=7.0) but varied from slightly acidic to alkaline (Table I). Secchi depth was low and turbidity was higher than 100 NTU in $20 \%$ of the systems (Table I).

Total and dissolved nitrogen and phosphorus concentrations varied widely. Median values of TP concentrations were high $\left(173 \mu \mathrm{g} \mathrm{L}^{-1}\right)$, but TN concentrations were not as high as expected (560 $\mu \mathrm{g} \mathrm{L}^{-1}$ ) (Table I). DIN and SRP concentrations were, on average, intermediate (median=79 and $12 \mu \mathrm{g} \mathrm{L}^{-1}$, respectively). We observed a weak but significant relationship between total phosphorus and chlorophyll- $a\left(\mathrm{r}_{\text {adj }}^{2}=0.16, \mathrm{p}=0.0157\right)$.

A trend for $\mathrm{N}$ limitation of phytoplankton growth was observed in most of the fishponds, if considered the median values of total $\mathrm{N}: \mathrm{P}$ ratios $(\mathrm{TN}: \mathrm{TP}=9.4)$. This is consistent if the algal requirements, based on the half-saturation constants for most algal species, are taken into account (see Methods section); by this criterion, $60 \%$ of the systems were $\mathrm{N}$-limited.

Therefore, on average, the fishponds were warm, with circumneutral water, low dissolved oxygen, and high turbidity. Total phosphorus concentrations were remarkably high, however, total nitrogen concentrations or dissolved inorganic nitrogen and phosphorus are not. Therefore, a trend of $\mathrm{N}$ limitation of phytoplankton growth was found.

PHYTOPLANKTON

Total phytoplankton abundance varied between $4.210^{3}$ and $7.310^{6}$ cells $\mathrm{mL}^{-1}$ in the fishponds. The most important group of the phytoplankton community in terms of abundance was cyanobacteria, which contributed, on average, $66 \%$ of the total phytoplankton abundance. Green algae were the second most abundant group, with 24\% (Figure 2).

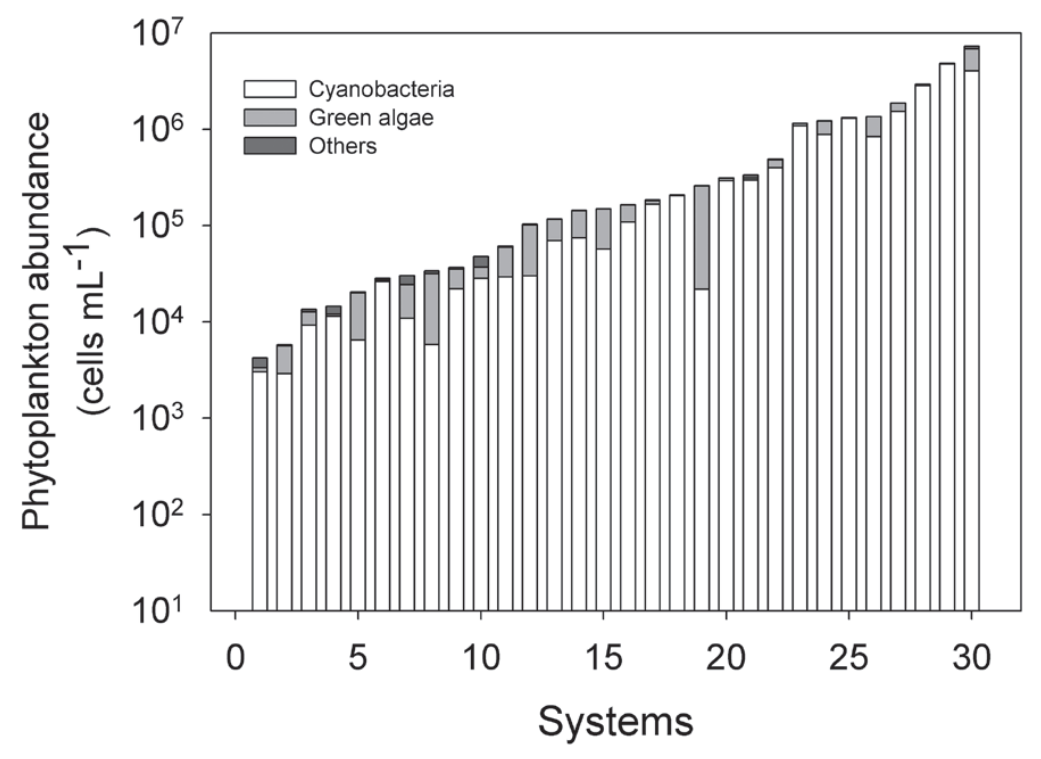

Figure 2 - Phytoplankton abundance (log scale) sorted by major taxonomic group, in 30 fishponds in southeastern Brazil. 
TABLE II

Main features of the aquaculture systems. org . = organic, inorg. = inorganic, multiple $=$ multiple species, mono $=$ monoculture.

\begin{tabular}{|c|c|c|c|c|c|c|c|c|}
\hline $\begin{array}{l}\text { System } \\
\text { number }\end{array}$ & $\begin{array}{c}\text { Lat. } \\
\text { (UTM) }\end{array}$ & $\begin{array}{l}\text { Long. } \\
\text { (UTM) }\end{array}$ & Type of activity & $\begin{array}{l}\text { Water } \\
\text { source }\end{array}$ & $\begin{array}{l}\text { Pond } \\
\text { bottom }\end{array}$ & $\begin{array}{l}\text { Rearing } \\
\text { system }\end{array}$ & $\begin{array}{l}\text { Stocking rate } \\
\quad\left(\text { fish } \mathrm{m}^{-2)}\right.\end{array}$ & $\begin{array}{l}\text { Type of } \\
\text { fertilizer }\end{array}$ \\
\hline \multicolumn{9}{|c|}{ Closed systems } \\
\hline 3 & 21.113 & 43.062 & fee-fishing & spring & earthen & multiple & 4 & none \\
\hline 9 & 22.423 & 43.391 & fee-fishing & spring & concrete & multiple & 1.5 & none \\
\hline 10 & 22.322 & 44.000 & fish-farming & unknown & earthen & mono & 2 & org. \\
\hline 11 & 22.402 & 43.403 & fee-fishing & stream & concrete & multiple & unknown & none \\
\hline 15 & 22.345 & 43.506 & fish-farming & spring & earthen & mono & 2.5 & org. + inorg. \\
\hline 17 & 22.351 & 42.474 & fish-farming & spring & earthen & multiple & 3 & org. + inorg. \\
\hline 18 & 22.323 & 42.466 & fish-farming & spring & earthen & multiple & 1.5 & org. + inorg. \\
\hline 19 & 22.342 & 42.415 & fish-farming & unknown & earthen & multiple & 2 & org. \\
\hline 20 & 22.300 & 42.115 & fish-farming & stream & earthen & mono & 1 & org. \\
\hline 21 & 22.295 & 42.131 & fish-farming & stream & earthen & mono & 1.5 & org. + inorg. \\
\hline 22 & 22.282 & 42.095 & fish-farming & spring & earthen & multiple & 3 & org. + inorg. \\
\hline 23 & 22.440 & 42.423 & fish-farming & spring & earthen & multiple & 1.5 & org. + inorg. \\
\hline 24 & 22.344 & 43.191 & fee-fishing & spring & earthen & multiple & unknown & none \\
\hline 25 & 22.364 & 43.191 & fish-farming & spring & earthen & multiple & 3.5 & org. + inorg. \\
\hline 27 & 22.052 & 43.186 & fish-farming & stream & earthen & multiple & 2 & org. \\
\hline 28 & 22.086 & 43.225 & fish-farming & spring & earthen & mono & 2 & org. + inorg. \\
\hline 29 & 22.095 & 43.321 & fish-farming & spring & earthen & multiple & 2 & org. \\
\hline 30 & 22.085 & 43.343 & fish-farming & spring & earthen & multiple & 2 & org. \\
\hline \multicolumn{9}{|c|}{ Open systems } \\
\hline 1 & 21.142 & 42.550 & fee-fishing & spring & earthen & mono & 1.5 & org. + inorg. \\
\hline 2 & 21.050 & 42.571 & fee-fishing & stream & earthen & multiple & unknown & none \\
\hline 4 & 21.152 & 42.082 & fish-farming & spring & earthen & mono & 2.5 & inorg. \\
\hline 5 & 21.241 & 42.094 & fee-fishing & spring & earthen & multiple & 1.5 & org. \\
\hline 6 & 22.322 & 44.001 & fee-fishing & unknown & earthen & multiple & unknown & org. \\
\hline 7 & 22.364 & 44.005 & fish-farming & spring & earthen & mono & 2.5 & org. + inorg. \\
\hline 8 & 22.421 & 43.575 & fee-fishing & spring & earthen & multiple & 3 & org. + inorg. \\
\hline 12 & 22.422 & 43.586 & fish-farming & spring & earthen & multiple & 2 & inorg. \\
\hline 13 & 22.384 & 44.004 & fee-fishing & spring & earthen & multiple & 1 & org. + inorg. \\
\hline 14 & 22.390 & 43.546 & fish-farming & spring & earthen & mono & 2 & org. + inorg. \\
\hline 16 & 22.343 & 42.472 & fish-farming & spring & earthen & mono & 1 & org. + inorg. \\
\hline 26 & 22.362 & 43.205 & fish-farming & spring & earthen & multiple & 1 & org. + inorg. \\
\hline
\end{tabular}


Systems with higher abundances of cyanobacteria $\left(>50,000\right.$ cells $\left.\mathrm{mL}^{-1}\right)$ were those with higher TP concentrations (Figure 3a) and chlorophyll- $a$. In 23 fishponds, cyanobacteria contributed more than $50 \%$ of the total phytoplankton abundance, and green algae contributed more than $50 \%$ in only three ponds. The most abundant species of cyanobacteria were Aphanocapsa delicatissima, A. incerta, A. elachista, Chrococcus cf. dispersus, $C$. minimus, Geitlerinema amphibium, Merismopedia tenuissima, Microcystis aeruginosa, Pannus mycrocystiformis, Planktolyngbya circumcreta, and Pseudanabaena cf. acicularis. The most abundant green algae were Desmodesmus communis, Dictyosphaerium pulchellum, Eudorina elegans, Kirchneriella dianae., Koliella longiseta f. tenuis,
Scenedesmus ellipticus, Crucigenia tetrapedia, Scenedesmus ovalternus, and Tetrastrum sp.

Of the 30 fishponds, 17 showed concentrations above 50,000 cells $\mathrm{mL}^{-1}$ of cyanobacteria and followed the gradient of chlorophyll- $a$ and TP concentrations (Figure 3a). Chlorophyll- $a$ concentrations ranged between 8.7 and $344.0 \mu \mathrm{g}$ $\mathrm{L}^{-1}$ (median $=82.0 \mu \mathrm{g} \mathrm{L}^{-1}$ ) and $90 \%$ of the systems showed levels higher than $30 \mu \mathrm{g} \mathrm{L}^{-1}$ (Table I).

Summarizing, cyanobacteria were highly abundant in most of our fishponds, and were the most important group, followed by green algae. Cyanobacteria abundance was positively related to TP concentrations, and they were more abundant in $\mathrm{N}$-limited systems (Figure 3a, b).

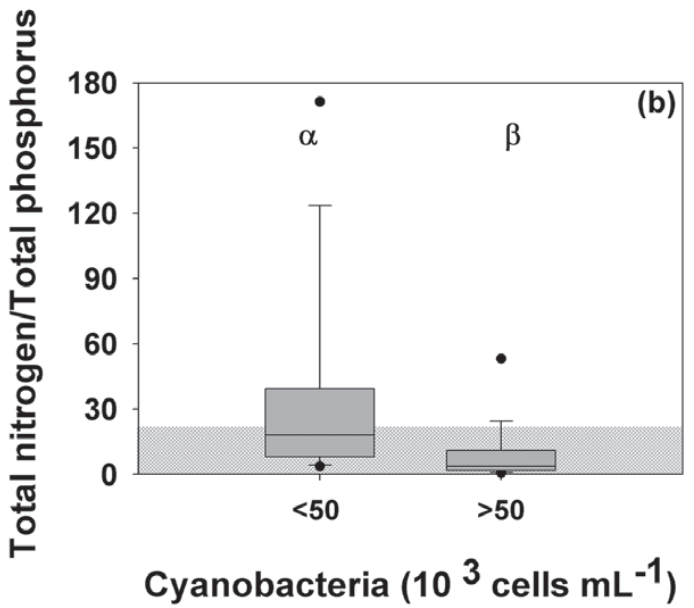

Figure 3 - (a) Relationship between Log Total phosphorus concentrations and Log Cyanobacterial abundance, showing the higher cyanobacterial abundance in higher TP concentrations; (b) Box plots of TN:TP ratios (by atom) in the fishponds where cyanobacteria abundances were higher and lower than 50,000 cells $\mathrm{mL}^{-1}$. The gray area indicates N limitation. Significant differences $(\mathrm{p}<0.05)$ are indicated by different letters.

\section{THERMOTOLERANT COLIFORMS}

The abundance of thermotolerant coliforms was highly variable (2 to $160,000 \mathrm{MPN} 100 \mathrm{~mL}^{-1}$ ) and numbers greater than $1,000 \mathrm{MPN} 100 \mathrm{~mL}^{-1}$ were found in $50 \%$ of the fishponds. Total phytoplankton and cyanobacteria abundances were positively related $(p<0.05)$ to the abundance of thermotolerant coliforms ( $\mathrm{r}_{\mathrm{S}}=0.18$ and 0.26 , respectively).

\section{CYANOTOXINS IN THE SESTON FRACTION AND FiSH MUSCLES}

In 2005, we selected five systems from the fishponds, with total abundance greater than 100,000 cells $\mathrm{mL}^{-1}$ to analyze microcystins in the seston and in the Nile tilapia muscle. The same analyses were repeated in the same ponds in 2008. Microcystins varied from zero to $0.17 \mu \mathrm{g} \mathrm{L}^{-1}$ in the seston, and from zero to $0.05 \mathrm{ng} \mathrm{g}^{-1}$ in fish muscle (Table III). 
In 2005, microcystins varied from zero (pond 25) to $0.11 \mu \mathrm{g} \mathrm{L}^{-1}$ (pond 18) in the seston and from 0.01 (pond 12) to $0.05 \mathrm{ng} \mathrm{g}^{-1}$ in fish muscle (ponds 20 and 25). In 2008, the variation of microcystins ranged from zero (ponds 24 and 25) to $0.16 \mu \mathrm{g} \mathrm{L}^{-1}$ (pond 12) in the seston, and from zero (pond 24) to
$0.02 \mathrm{ng} \mathrm{g}^{-1}$ (pond 18) in fish muscle. The highest level in fish muscle was found in ponds 20 and 25 $\left(0.05 \mathrm{ng} \mathrm{g}^{-1}\right)$ in 2005 . Pond 25 showed the highest cyanobacteria abundance $\left(1,295,751\right.$ cells $\left.\mathrm{mL}^{-1}\right)$. Surprisingly, microcystins were detected in the seston of pond 20 but not in pond 25 (Table III).

TABLE III

Microcystins in the seston fraction and fish muscle, in five tropical fishponds in southeastern Brazil with high cyanobacterial abundance, in 2005 and 2008. (*Samples not analyzed).

\begin{tabular}{|c|c|c|c|c|c|}
\hline Fishponds & Years & $\begin{array}{l}\text { Microcystin- } \\
\text { seston }\left(\mu \mathrm{g} \mathrm{L}^{-1}\right)\end{array}$ & $\begin{array}{l}\text { Microcystin-fish } \\
\text { muscle }\left(\mathrm{ng} \mathrm{g}^{-1}\right)\end{array}$ & $\begin{array}{l}\text { Cyanobacteria } \\
\left(\text { cells } \mathrm{mL}^{-1}\right)\end{array}$ & Main species \\
\hline \multirow{3}{*}{12} & \multirow{3}{*}{$\begin{array}{l}2005 \\
2008\end{array}$} & \multirow{2}{*}{0.02} & \multirow{2}{*}{0.01} & \multirow{2}{*}{30.038} & \multirow{3}{*}{$\begin{array}{c}\text { Planktolyngbya sp.1 } \\
\text { Planktolyngbya limnetica } \\
\text { Aphanocapsa incerta }\end{array}$} \\
\hline & & & & & \\
\hline & & 0.16 & 0.01 & 153.455 & \\
\hline \multirow{4}{*}{18} & \multirow[b]{2}{*}{2005} & \multirow[b]{2}{*}{0.11} & \multirow[b]{2}{*}{ * } & \multirow[b]{2}{*}{204.108} & Synechocystis sp.2 \\
\hline & & & & & Pannus microcystiformis \\
\hline & \multirow{2}{*}{2008} & \multirow[t]{2}{*}{0.08} & \multirow[t]{2}{*}{0.02} & \multirow[t]{2}{*}{418.762} & Aphanocapsa delicatissima \\
\hline & & & & & A. incerta \\
\hline \multirow{4}{*}{20} & \multirow[b]{2}{*}{2005} & \multirow[b]{2}{*}{0.03} & \multirow[b]{2}{*}{0.05} & \multirow[b]{2}{*}{291.977} & A. incerta \\
\hline & & & & & A. delicatissima \\
\hline & \multirow{2}{*}{2008} & \multirow[t]{2}{*}{0.01} & \multirow[t]{2}{*}{$*$} & \multirow[t]{2}{*}{756.553} & Aphanocapsa holsatica \\
\hline & & & & & A. incerta \\
\hline \multirow{3}{*}{24} & \multirow{3}{*}{$\begin{array}{l}2005 \\
2008\end{array}$} & 0.01 & 0.04 & \multirow{2}{*}{879.356} & Pseudanabaena cf. acicularis \\
\hline & & \multirow{2}{*}{0.00} & \multirow{2}{*}{0.00} & & A. delicatissima \\
\hline & & & & 197.115 & A. incerta \\
\hline \multirow{6}{*}{25} & \multirow{3}{*}{2005} & \multirow{3}{*}{0.00} & \multirow{3}{*}{0.05} & & Microcystis cf. aeruginosa \\
\hline & & & & 1.295 .751 & Synechocystis aquatilis \\
\hline & & & & & A. incerta \\
\hline & & & & & Microcystis sp. \\
\hline & 2008 & 0.17 & 0.01 & 931.972 & A. holsatica \\
\hline & & & & & Merismopedia tenuissima \\
\hline
\end{tabular}

The most important cyanobacteria species were Pannus mycrocystiformis (ponds 12 and 18); Aphanocapsa incerta, A. delicatissima, and $A$. holsatica (ponds 12, 18, 20, 24 and 25); Planktolyngbya limnetica (pond 12); Synechocystis aquatilis (ponds 18 and 25); Microcystis aeruginosa (pond 25); and Pseudanabaena sp. (pond 24).

Therefore, microcystin concentrations both in the seston fraction and in fish muscle were low, even though the systems showed high cyanobacterial abundance.

\section{ESTABLISHED PARAMETERS FOR WATER QUALITY}

About half of the fishponds indicated less than the allowed $5 \mathrm{mg} \mathrm{L}^{-1}$ of dissolved oxygen, and $80 \%$ showed turbidity lower than 100 NTU. In $90 \%$ of the systems, the total phosphorus content was higher than the threshold of $50 \mu \mathrm{g} \mathrm{L}^{-1}$ and chlorophyll- $a$ 
TABLE IV

Established parameters for Class II water quality, indicated by Brazilian legislation (CONAMA 357/2005) for aquaculture and fishing activities, and results for 30 fishponds in the state of Rio de Janeiro.(MPN = most probable number). In bold, parameters exceeding the mandated limits. ${ }^{*} \mathbf{p}<0.05 ; * * \mathbf{p}<0.1$; Max=maximum.

\begin{tabular}{|c|c|c|c|c|c|c|}
\hline $\begin{array}{l}\text { Parameters/ } \\
\text { Systems }\end{array}$ & $\begin{array}{l}\text { Dissolved } \\
\text { oxygen } \\
\left(\mathrm{mg} \mathrm{L}^{-1}\right)\end{array}$ & $\begin{array}{c}\text { Turbidity } \\
\text { (NTU) }\end{array}$ & $\begin{array}{c}\text { Total } \\
\text { phosphorus } \\
\left(\mu g P L^{-1}\right)\end{array}$ & $\begin{array}{l}\text { Chlorophyll-a } \\
\left(\mu \mathrm{g} \mathrm{L}^{-1}\right)\end{array}$ & $\begin{array}{c}\text { Thermotolerant } \\
\text { coliforms } \\
\left(10^{3} \mathrm{MPN} 100 \mathrm{~mL}^{-1}\right)\end{array}$ & $\begin{array}{c}\text { Cyanobacterial } \\
\text { abundance } \\
\left(10^{3} \text { cells } \mathrm{mL}^{-1}\right)\end{array}$ \\
\hline $\begin{array}{l}\text { Max. values } \\
\text { allowed }\end{array}$ & $>5$ & $<100$ & $<\mathbf{5 0}$ & $<\mathbf{3 0}$ & $<1$ & $<\mathbf{5 0 , 0 0 0}$ \\
\hline \multicolumn{7}{|c|}{ Closed systems } \\
\hline 3 & 10.2 & 12.9 & 174.5 & 86.9 & 90 & 30.0 \\
\hline 9 & 4.2 & 34.0 & 104.4 & 55.2 & 2.3 & 2.9 \\
\hline 10 & 6.4 & 139.8 & 439.3 & 45.7 & 90.0 & 204.1 \\
\hline 11 & 12.8 & 21.0 & 111.7 & 256.2 & 8.0 & 395.8 \\
\hline 15 & 3.0 & 45.9 & 61.2 & 80.2 & 2.0 & 11.4 \\
\hline 17 & 3.8 & 36.7 & 171.1 & 74.2 & 16.0 & 69.5 \\
\hline 18 & 6.5 & 43.2 & 113.9 & 52.0 & 3.0 & 22.0 \\
\hline 19 & 7.0 & 50.2 & 182.3 & 78.2 & 17.0 & 166.3 \\
\hline 20 & 4.7 & 51.7 & 103.2 & 28.0 & 0.1 & 5.8 \\
\hline 21 & 5.9 & 101.6 & 308.3 & 141.9 & 0.2 & 10.9 \\
\hline 22 & 4.3 & 114 & 207.4 & 344 & 0.1 & 108.4 \\
\hline 23 & 7.8 & 33.9 & 78.3 & 49.0 & 23.0 & 26.1 \\
\hline 24 & 7.1 & 13.0 & 48.8 & 59.0 & 0.3 & 29.1 \\
\hline 25 & 5.3 & 126.3 & 300.7 & 166.8 & 0.7 & 56.9 \\
\hline 27 & 3.3 & 86.8 & 172 & 83.7 & 0.1 & 1088.6 \\
\hline 28 & 3.5 & 62.0 & 96.5 & 103.2 & 0.1 & 74.5 \\
\hline 29 & 4.4 & 16.6 & 33.4 & 8.7 & 0.1 & 3.0 \\
\hline 30 & 3.9 & 21.5 & 85.0 & 69.2 & 0.2 & 21.8 \\
\hline Mean & 5.8 & 56.2 & $160.6 *$ & 99.0 & $14.1 * *$ & $129.3 *$ \\
\hline \multicolumn{7}{|c|}{ Open systems } \\
\hline 1 & 4.1 & 76.4 & 85.2 & 50.3 & 17.0 & 294.4 \\
\hline 2 & 6.8 & 262.9 & 249.7 & 91.7 & 160.0 & 9.2 \\
\hline 4 & 3.4 & 83.2 & 195.8 & 288.1 & 8.0 & 2809.7 \\
\hline 5 & 9.3 & 56.7 & 297,0 & 96.2 & 13.0 & 291.9 \\
\hline 6 & 4.2 & 42.5 & 257.3 & 134.1 & 160.0 & 837.8 \\
\hline 7 & 10.2 & 97.9 & 669.5 & 84.0 & 160.0 & 4758.2 \\
\hline 8 & 8.8 & 9.9 & 55.9 & 41.2 & 22.0 & 28.3 \\
\hline 12 & 1.2 & 101.6 & 665.4 & 88.0 & 0.7 & 1522.9 \\
\hline 13 & 4.0 & 95.3 & 520.9 & 92.8 & 0.2 & 1295.8 \\
\hline 14 & 6.7 & 17.6 & 44.5 & 64.3 & 0.3 & 6.4 \\
\hline 16 & 2.8 & 35.2 & 229.3 & 18.0 & 0.2 & 879.3 \\
\hline 26 & 4.8 & 67.0 & 337.0 & 300.0 & 0.1 & 4048.9 \\
\hline Mean & 5.5 & 78.9 & $300.6 *$ & 112.4 & $45.1 * *$ & $1398.6 *$ \\
\hline
\end{tabular}


was higher than $30 \mu \mathrm{g} \mathrm{L}^{-1}$. Cyanobacteria abundance was higher than 50,000 cells $\mathrm{mL}^{-1}$ in $57 \%$ of the fishponds and thermotolerant coliforms were higher than $1000 \mathrm{MPN} 100 \mathrm{~mL}^{-1}$ in $56 \%$ of the ponds (Table IV). There was no single system where all variables were within the accepted range of water quality for fish culture.

\section{DISCUSSION}

In evaluating the water quality in 30 fishponds in southeastern Brazil, we found that they were highly phosphorus-enriched, due to fertilization, which lowered the water quality by increasing cyanobacteria, chlorophyll- $a$, turbidity, and thermotolerant coliforms, and by depleting dissolved oxygen.

As established in many previous studies, low water quality is expected in fish ponds (Boyd and Queiroz 2001, Mercante et al. 2004, Boyd 2006). The consequences of fertilization are related to the increase in nutrient availability, mainly phosphorus (Zhang and Fang 2006). Non-consumed fish ration remains in the system and leads to algal blooms, especially cyanobacteria, high chlorophyll- $a$ concentrations (Mercante et al. 2004), high levels of turbidity and oxygen depletion (Simões et al. 2008). These effects, as well as high levels of thermotolerant coliforms, were found in the fishponds. Most of these variables are related to the eutrophication process.

According to criteria proposed by Nürnberg (1996), of the 30 fishponds, 21 were hypereutrophic and nine eutrophic, based on TP concentrations. A stronger trend was observed when trophic states were established based on chlorophyll- $a$ : almost all the systems (28) were hypereutrophic. Although the TP concentrations were remarkably high, the TN concentrations did not follow proportionately high. Using TN as the indicator, 12 systems were eutrophic and hypereutrophic, 12 were mesotrophic, and 6 oligotrophic. This situation is commonly found in tropical waters (Brasil 2011, Rangel et al. 2012) probably because of the potential higher denitrification rates at warmer temperatures (Lewis 2000). For this reason, it has been argued that in tropical latitudes, $\mathrm{N}$ can be the most frequent limiting nutrient for phytoplankton growth (Lewis 2000). However, this finding has not been supported by the most recent studies (Huszar et al. 2006, Elser et al. 2007, Kosten et al. 2009), and there is no statistically significant relationship between latitude and denitrification rates in the warmest season (PiñaOchoa and Álvarez-Cobelas 2006).

Independently of the causes of the low amount of nitrogen in our fishponds, the trend for $\mathrm{N}$ limitation of phytoplankton growth was clear, as shown by both the criteria of dissolved inorganic nitrogen concentrations and TN:TP ratios. The conditions of low TN:TP ratios (Smith 1983, Bulgakóv and Levich 1999), high total phosphorus concentrations (Moss et al. 2011), allied to the high temperature (Paerl and Huisman 2008, Lürling et al. 2013) might favor the dominance of cyanobacteria. In fact, the abundance of this algal group was positively related to TP concentrations, and cyanobacteria were more abundant in the $\mathrm{N}$-limited fishponds.

Cyanobacteria dominance is potentially related to cyanotoxin production (Huisman et al. 2005). Despite the importance of information on bioaccumulation of cyanotoxins in fish muscle (Magalhães et al. 2003, Soares et al. 2004, Ibelings and Chorus 2007, Romo et al. 2012), knowledge of this factor in fishponds is still sparse. Our data revealed low levels of microcystins both in the seston and in fish muscle, in spite of the high cyanobacteria abundance in these systems. There are several possible explanations for this finding. First, among the most important cyanobacteria in the systems where cyanotoxins were analyzed, only three species were potential producers of toxic microcystins (Planktolyngbya limnetica, Synechocystis aquatilis and Microcystis aeruginosa; Sant'Anna et al. 2008). Second, the particular strains present may have been non-toxic. Third, 
the period of exposure to the algae may have been insufficient for toxins to be accumulated by the omnivorous filter-feeding Nile tilapia, the main species reared in the fish farms. Cyanotoxins in fish muscle were below the limit of the Tolerable Daily Intake (TDI). According to Chorus and Bartram (1999), the TDI value of microcystins is $0.04 \mu \mathrm{g} \mathrm{kg}^{-1}$ body weight $\mathrm{d}^{-1}$. Therefore, if an adult human weighing $60 \mathrm{~kg}$ ingests $300 \mathrm{~g}$ of fish muscle, the microcystin level of $0.05 \mathrm{ng} \mathrm{g}^{-1}$ in fish muscle in the estimated daily intake will be $0.00025 \mu \mathrm{g}$ of microcystin per kilogram of human body weight. This value is 160 -fold lower than the TDI suggested by Chorus and Bartram (1999) for this cyanotoxin. Further investigations should more thoroughly examine cyanotoxin levels in fish muscles and viscera, to better understand the bioaccumulation process.

Highly enriched fishponds with high concentrations of total phytoplankton and cyanobacteria also have high numbers of thermotolerant coliforms, indicating the decline in water quality. Organic fertilizers (bird and pig manure) are commonly used in these fishponds, and domestic animals are also present in the vicinity (unpublished data).

Based on our data, it was possible to evaluate the water quality of these fishponds with reference to the Brazilian legislation to classify inland waterbodies (CONAMA 357/2005). The classification is based on turbidity, total phosphorus, dissolved oxygen, chlorophyll- $a$, cyanobacteria abundance, and ther- motolerant coliforms, among other variables. We found that all 30 systems were inappropriate for fish culture, for at least one of the parameters measured. Among the six parameters evaluated in this paper, $63 \%$ of the systems exceeded the regulated limits for at least four of the items of which phosphorus and chlorophyll- $a$ were the most common. Open systems supported significantly higher TP concentrations and cyanobacterial abundance $(p<0.05)$ than closed systems. Thermotolerant coliforms were also found in higher concentrations (marginally significant, $\mathrm{p}=0.07$ ) in open fishponds than in closed ones. Because the samples were taken during the rainy season, the open systems seemed to be more vulnerable to nutrient input from the watershed. Therefore, in these systems, in addition to the input from fertilizers and the internal loading, external loading could also have contributed to the eutrophication process. As a consequence, cyanobacterial abundance also increased, reducing the water quality. For example, the fish-farming ponds with the highest levels of TP and highest cyanobacterial abundances were open systems (7 and 12). The interaction of the management practices with land uses in the watersheds, modulated by regional climate, could accelerate the eutrophication process in the fishponds. Similar conditions have been found in other aquaculture systems in the Upper Tietê River and Mogi-Guaçu River basins, state of São Paulo (Sant'Anna et al. 2006, Eler and Espíndola 2006) (Table V). However, although

TABLE V

Comparison of the variables used to evaluate water quality in this study, with other similar studies in Brazil. * Sant'Anna et al. 2006, ** Eler and Espíndola 2006. n.i.=not informed.

\begin{tabular}{c|ccc|ccc|cccc}
\hline & \multicolumn{3}{|c|}{ Upper Tietê River* } & \multicolumn{2}{c|}{ Mogi-Guaçu River** } & \multicolumn{4}{c}{ This study } \\
& Range & Mean & SD & Range & Mean & SD & Range & Mean & SD \\
\hline \multirow{2}{*}{ Dissolved oxygen $\left(\mathrm{mg} \mathrm{L}^{-1}\right)$} & $4.4-13.5$ & 7.8 & n.i. & $0.31-11.6$ & 6.9 & 2.2 & $1.2-12.8$ & 5.7 & 2.6 \\
Turbidity $(\mathrm{NTU})$ & $14.0-235$ & 45.9 & n.i. & $2.0-239.0$ & 32.7 & 45.4 & $9.9-262.9$ & 65.2 & 52.1 \\
Total phosphorus $\left(\mu \mathrm{g} \mathrm{L}^{-1}\right)$ & $35.0-315.0$ & 115 & n.i. & $3.7-335.5$ & 130.8 & 88.3 & $33.4-669.5$ & 213.3 & 171.4 \\
Chlorophyll- $a\left(\mu \mathrm{g} \mathrm{L}^{-1}\right)$ & $0.0-300.0$ & 50 & n.i. & $254.0-327.4$ & n.i. & n.i. & $8.7-344.0$ & 104.4 & 84.8 \\
\hline
\end{tabular}


turbidity, total phosphorus and chlorophyll-a concentrations were in the same range, higher mean values were found in the fishponds in the state of Rio de Janeiro.

In synthesis, high nutrient concentrations, mainly phosphorus, cause low water quality in these fishponds by increasing cyanobacteria, chlorophyll- $a$, turbidity, and thermotolerant coliforms, and by depleting dissolved oxygen. Our findings indicate the need for better management practices to minimize the impacts of the eutrophication process, in addition to rigorous control policies for these systems, in order to guarantee food quality.

\section{ACKNOWLEDGMENTS}

Special thanks to the owners of the 30 fishponds, who cooperated with this study, and to Prof. Sandra M. F. Azevedo, Instituto de Biofísica, Universidade Federal do Rio de Janeiro for her support with the toxin analyses and to Marcio Malafaia for the map construction. The research was supported by Coordenação de Aperfeiçoamento de Pessoal de Nível Superior (CAPES), Brazil, grant 31001017014P9; VH was partially supported by the Conselho Nacional de Desenvolvimento Científico e Tecnológico (CNPq), grant 307727/2009-2.

\section{RESUMO}

A expansão da aquicultura no mundo tem causado fortes impactos ambientais. Um dos principais impactos é a eutrofização, por causa do necessário uso de fertilizantes para o crescimento de peixes, o que resulta em baixa qualidade da água e promove florações de algas, sobretudo de cianobactérias. Para avaliar se a qualidade da água em 30 sistemas de pisciculturas no sudeste do Brasil atinge os requerimentos da legislação brasileira, foram analisadas as condições bióticas e abióticas da água. Espera-se que os altos níveis de nutrientes ocasionados pela fertilização promovam uma redução na qualidade da água. Nós também analisamos cianotoxinas no seston e no músculo dos peixes em alguns sistemas onde cianobactérias foram dominantes.
Os sistemas de pisciculturas variaram de eutróficos a hipereutróficos com altas biomassas de cianobactérias. Apesar das cianobactérias serem dominantes na maioria dos sistemas, cianotoxinas ocorreram em baixas concentrações provavelmente porque somente duas das 12 espécies dominantes foram potencialmente produtoras de microcistinas. As altas concentrações de fósforo promoveram baixa qualidade da água, com aumento de cianobactérias, clorofila- $a$, turbidez e de coliformes termotolerantes e com depleção do oxigênio dissolvido. De acordo com a legislação brasileira, todos os 30 sistemas foram considerados inapropriados para o cultivo de peixes, em pelo menos um dos parâmetros medidos. Além disso, nenhum dos sistemas apresentou todas as variáveis de qualidade da água analisadas dentro dos limites aceitos para sistemas destinados ao cultivo de peixes, de acordo com a legislação brasileira. Nossos resultados indicam a necessidade de um melhor manejo e um rigoroso controle dos sistemas de aquicultura para minimizar os impactos da eutrofização e garantir uma boa qualidade do alimento produzido.

Palavras-chave: cianobactéria, cianotoxinas, eutrofização, pisciculturas.

\section{REFERENCES}

APHA. 2005. Standard methods for the examination of water and wastewater, $21^{\text {st }}$ ed., Washington, DC: American Public Health Association, 1220 p.

BOYD CE. 2006. Sustainable aquaculture practices: phytoplankton dynamics in aquaculture ponds. Global Aquacult Advocate Nov/Dec: 67-68.

BOYD CE AND QUEIROZ J. 1997. Manejo do solo e da qualidade da água em viveiro para aquicultura. Campinas: ASA, 55 p.

BOYD CE AND QUEIROZ J. 2001. Feasibility of retention structure, settling basins and best management practices in effluent regulation for Alabama Channel Catfish Farming. Rev Fish Sci 9: 43-67.

Boyd CE, Wood CW, Chaney PL AND QueIroz JF. 2010. Role of aquaculture pond sediments in sequestration of annual global carbon emissions. Environ Pollut 158: 2537-2540.

BRASIL J. 2011. Ecologia do fitoplâncton em reservatórios do semi-árido brasileiro: da abordagem funcional da comunidade à variabilidade intra-específica. Tese de Doutorado. Programa de Pós-graduação em Ecologia, UFRJ.

Bulgakóv NG AND LEVICH AP. 1999. The nitrogen: phosphorus ratio as a factor regulating phytoplankton community structure. Arch Hydrobiol 146: 3-22. 
CaO L, Wang W, Yang Y, Yang C, Yuan Z, Xiong S And DIANA J. 2007. Environmental impact of aquaculture and counter measures to aquaculture pollution in China. Environ Sci Pollut R 14: 452-462.

CARACO NF AND Miller R. 1998. Effects of $\mathrm{CO}_{2}$ on competition between a cyanobacterium and eukaryotic phytoplankton. Can J Fish Aquat Sci 55: 54-62.

CARMichael WW. 1997. The Cyanotoxins. Advances in Botanical Research, no. 27. Waltham, USA: Academic Press, p. 211-255.

CHORUS I AND BARTRAM J. 1999. Toxic cyanobacteria in water: a guide to their public health consequences, monitoring and management. London: E \& FN Spon, 416 p.

CONAMA - CONSElHo NACIONAL do MeIo Ambiente. 2005. Classificação das águas doces, salobras e salinas do território Nacional. Resolução no. 357, 17 March 2005. Ministério do Meio Ambiente, Brasil.

Dzialowski AR, Smith VH, Huggins DG, Denoyelles F, LIM NC, BAKER DS AND BEURY JH. 2009. Development of predictive models for geosmin-related taste and odor in Kansas, USA, drinking water reservoirs. Water Res 43: 2829-2840.

ELER MN AND ESPÍNDOLA ELG. 2006. Avaliação do impacto ambiental de pesque-pague: Uma análise da atividade na bacia hidrográfica do rio Mogi-Guaçu. São Carlos: Editora RiMa, 312 p.

Elser JJ, Bracken MES, Cleland EE, GRUNER DS, HARPole WS, Hillebrand H, Ngai JT, Seabloom EW, Shurin JB AND SMITH JE. 2007. Global analysis of nitrogen and phosphorus limitation of primary producers in freshwater, marine and terrestrial ecosystems. Ecol Lett 10: 1135-1142.

HARGREAVES JA AND TUCKER CS. 2003. Defining loading limits of static ponds for catfish aquaculture. Aquacult Eng 28: 47-63.

Hu Z, LEe JW, Chandran K, Kim S AND Khanal SK. 2012 Nitrous oxide $\left(\mathrm{N}_{2} \mathrm{O}\right)$ emission from aquaculture: a review. Environ Sci Technol 46: 6470-6480.

Huisman J, MatThiss HCP AND Visser PM. 2005. Harmful Cyanobacteria. Dordrecht: Springer, 243 p.

Huszar VLM, CARACo NF, Roland F AND COLE JJ. 2006. Nutrient-chlorophyll relationships in tropical-subtropical lakes: do temperate models fit? Biogeochemistry 79: 239-250.

IBELINGS BW AND CHORUS I. 2007. Accumulation of cyanobacterial toxins in freshwater "seafood" and its consequences for public health: a review. Environ Pollut 150: $177-192$.

KOSTEN S ET AL. 2012. Warmer climates boost cyanobacterial dominance in shallow lakes. Glob Change Biol 18: 118-126.

Kosten S, Huszar VLM, Mazzeo N, Scheffer M, STERNBERG LS AND JEPPESEN E. 2009. Lake and watershed characteristics rather than climate influence nutrient limitation in shallow lakes. Ecol Appl 19: 1791-1804.

LEWIS WM. 2000. Basis for protection and management of tropical lakes. Lakes Reserv Res Manage 5: 35-48.

Loureiro BR, Costa SM, MAcedo CF, Branco CC AND HuSZAR VLM. 2011. Comunidades zooplanctônicas em sistemas de criação de peixes no Estado do Rio de Janeiro. Bol Inst Pesca 37: 47-60.
LÜRLING M, ESHETU F, FAASSEN E, KOSTEN S AND HUSZAR VLM. 2013. Comparison of cyanobacterial and green algal growth rates at different temperatures. Freshwater Biol 58: 552-559.

MACKERETH FJH, Heron J AND TALLING JF. 1978. Water analysis: Some revised methods for limnologists. Freshwater Biological Association: Scientific Publication, p. 36-121.

Magalhães VF, Marinho MM, DOMINGos P, OliveIRA AC, Costa SM, Azevedo LO AND Azevedo SMFO. 2003. Microcystins (Cyanobacteria hepatotoxins) bioaccumulation in fish and crustaceans from Sepetiba Bay (Brazil, RJ). Toxicon 42: 289-295.

Magalhães VF, SOARES RM AND AZEVEdo S. 2001 Microcystin contamination in fish from the Jacarepaguá Lagoon (Rio de Janeiro, Brazil): ecological implication and human health risk. Toxicon 39: 1077-1085.

Mercante CTJ, Cabianca MA, Silva D, Costa SV AND ESTEVES KE. 2004. Water quality in fee-fishing ponds located in the metropolitan region of São Paulo city, Brazil: an analysis of the eutrophication process. Acta Limnol Bras 16: 95-102.

Minillo A AND MonTAgnolli W. 2006. Eutrofização e florações de cianobactérias tóxicas em tanques de pisciculturas e pesque-pagues: Avaliação de riscos e boas práticas de manejo e controle a esta problemática. In: ELER MN and ESPÍNDOLA ELG (Orgs), Avaliação dos impactos de pesque-pague: uma análise da atividade na bacia hidrográfica do rio Mogi-Guaçu, São Carlos: Editora RiMa, p. 227-245.

Moss B ET AL. 2011. Allied attack: climate change and eutrophication. Inland Waters 1: 101-105.

NEORI A. 2011. "Green water" microalgae: the leading sector in world aquaculture. J Appl Phycol 23: 143-149.

NÜRNBERG GK. 1996. Trophic state of clear and colored, softand hardwater with special consideration of nutrients, anoxia, phytoplankton and fish. J Lake Reserv Manage 12: 432-447.

PAERL HW AND Huisman J. 2008. Blooms like it hot. Science 320: 57-58.

PAERL HW AND HUISMAN J. 2009. Climate change: a catalyst for global expansion of harmful cyanobacterial blooms. Environ Microbiol Reports 1: 27-37.

PAERL HW, NATHAN SH AND CALANDRINO ES. 2011. Controlling harmful cyanobacterial blooms in a world experiencing anthropogenic and climatic-induced change. Sci Total Environ 409: 1739-1745.

Pelletier NL, Ayer NW, Tyedmers PH, Kruse SA, Flysjo A, Robillard G, ZIEGler F, ScholZ AJ AND SONESSON U. 2007. Impact categories for life cycle assessment research of seafood production systems: review and prospectus. Int J Life Cycle Ass 12: 414-421.

Phan-VAn M, Rousseau D AND De PauW N. 2008. Effects of fish bioturbation on the vertical distribution of water temperature and dissolved oxygen in a fish cultureintegrated waste stabilization pond system in Vietnam. Aquaculture 281: 28-33. 
PIÑA-OCHOAEAND ÁlvarEZ-CoBELAS M. 2006. Denitrification in aquatic environments: a cross-system analysis. Biogeochemistry 81: 111-130.

Rangel LM, Silva LHS, Rosa P, Roland F AND Huszar VLM. 2012. Phytoplankton biomass is mainly controlled by hydrology and phosphorus concentrations in tropical hydroelectric reservoirs. Hydrobiologia 693: 13-28.

REYNOLDS CS. 1997. Vegetation processes in the pelagic: a model for ecosystem theory. Oldendorf/Luhe, Germany: Ecology Institute, $371 \mathrm{p}$

REYNOLDS CS. 1999. Non-determinism to probability, or $\mathrm{N}: \mathrm{P}$ in the community ecology of phytoplankton. Arch Hydrobiol 146: 23-35.

Romo S, Fernández F, OUAHID Y AND BARÓN-SOlA Á. 2012. Assessment of microcystins in lake water and fish (Mugilidae, Liza sp.) in the largest Spanish coastal lake. Environ Monit Assess 184: 939-949.

SAKAмото M. 1966. Primary production by phytoplankton community in some Japanese lakes and its dependence on lake depth. Arch Hydrobiol 62: 1-28.

SAMUEl-Fitwir WS, Schroeder JP AND Schulz C. 2012. Sustainability assessment tools to support aquaculture development. J Clean Prod 32: 183-192.

SANT'ANna CL, AZEVEdo MT, Werner VR, Dogo CR, Rios FR AND CARVALHO LR. 2008. Review of toxic species of Cyanobacteria in Brazil. Algol Stud 126: 249-263.

SANT'ANNA CL, GENTIL RC AND SILVA D. 2006. Fitoplâncton de pesqueiros da região metropolitana de São Paulo. In: ESTEVES C and SANT'ANNA CL (Orgs), Pesqueiros da região Metropolitana de São Paulo: aspectos de monitoramento, ecológico e de saúde pública. São Carlos: Editora RiMa, p. 49-62.

SAS H. 1989. Lake restoration by reduction of nutrient loading: expectations, experiences, extrapolations. St. Augustin, Germany: Academia Verlag Richarz, 497 p.

SCHEFFER M, RinAldi S, GRAGNANi A, Mur LR AND VAN NeS EH. 1997. On the dominance of filamentous cyanobacteria in shallow, turbid lakes. Ecology 78: 272-282.
SIMERJ - SECRETARIA DE METEREOlogia do Estado DO RIO DE JANEIRO. 2011. Available at www.simerj.com. Accessed on October 25, 2011.

SiMÕES FS, MOREIRA AB, BISINOTI MC, GIMENEZ SMN AND YABE MJS. 2008. Water quality index as a simple indicator of aquaculture effects on aquatic bodies. Ecol Ind 8: 476-484.

SMITH VH. 1983. Low nitrogen to phosphorus ratios favor dominance by blue-green algae in lake phytoplankton. Science 221: 669-671.

SMITH VH. 1986. Light and nutrient effects on the relative biomass of blue-green algae in lake phytoplankton. Can J Fish Aquat Sci 43: 148-153.

SOARES RM, MAGAlHÃES VF AND AZEVEDO SMFO. 2004. Accumulation and depuration of microcystins (cyanobacteria hepatotoxins) in Tilapia rendalli (Cichlidae) under laboratory conditions. Aquat Toxicol 70: 1-10.

TRIMBEE AM AND PREPAS EE. 1987. Evaluation of total phosphorus as a predictor of the relative biomass of bluegreen algae with emphasis on Alberta lakes. Can J Fish Aquat Sci 44: 1337-1342.

UTERMÖHL H. 1958. Zur Vervollkommung der quantitativen Phytoplankton-Methodik. Mitt Int Ver Theor Angew Limnol 9: 1-38.

Wetzel RG And LiKens GE. 1990. Limnological Analyses. New York: Springer-Verlag, 291 p.

YoKOYAMA H. 2003. Environmental quality criteria for fish farms in Japan. Aquaculture 226: 45-56.

Zhang C, Mai K, Ai Q, Zhang W, Duan Q, Tan B, Ma H, XU W, LiUfu Z AND WANG X. 2006. Dietary phosphorus requirement of juvenile Japanese seabass, Lateolabrax japonicus. Aquaculture 255: 201-209.

ZHANG M AND FANG L. 2006. Phosphorus accumulation and eutrophication in feed-supply freshwater fishponds. J Env Sci 18: 816-821. 